\title{
Moderate takes key science role in Congress
}

Colin Macilwain, Washington

A moderate Republican with a keen interest in environmental and energy issues has been named as chair the Science Committee in the US House of Representatives.

The selection of Sherwood Boehlert (Republican, New York) to head the panel is good news for the scientific community at a time when it awaits, with uncertainty and even some trepidation, news of the science administrators in President George W. Bush's administration.

Sherry Boehlert is regarded as smart, sympathetic to science and - critically for the science panel - effective at getting results in Congress. Since 1995, when Republicans won control of the House, Boehlert has skilfully exploited his position as a moderate Republican to foster influence, especially on environmental policy.

"I'm looking forward to an exciting couple of years," Boehlert said in an interview the day after his selection. "Science policy is of critical importance to our future as a nation." He pledged to work for additional funding for the National Science Foundation (NSF), the National Institutes of Standards and Technology (NIST), and other agencies under the committee's jurisdiction.

"We've got a wide-open portfolio, and it would be presumptuous of me to lay out an agenda at this stage. But one thing we will need to do is to help to develop a comprehensive, coherent energy policy."

The Science Committee oversees most

\section{Biologists crusade for evolution}

Rex Dalton, Chicago

A newly energized effort to promote the teaching of evolution is underway across the United States, spurred by scientists who think the time is ripe to combat the creationist movement.

At its annual meeting last week, the Society for Integrative and Comparative Biology (SICB) became one of about a dozen organizations that have recently adopted policies to boost the teaching of evolution at all levels of education.

The drive follows the National Conference on the Teaching of Evolution, held at the University of California at Berkeley, where representatives of nearly 50 organizations met in October to plot a national consensus on promoting the teaching of evolution.

Individual societies - ranging from large organizations like the American Institute of Biological Sciences to small groups like the Association of Systematics Collections - are being urged to encourage

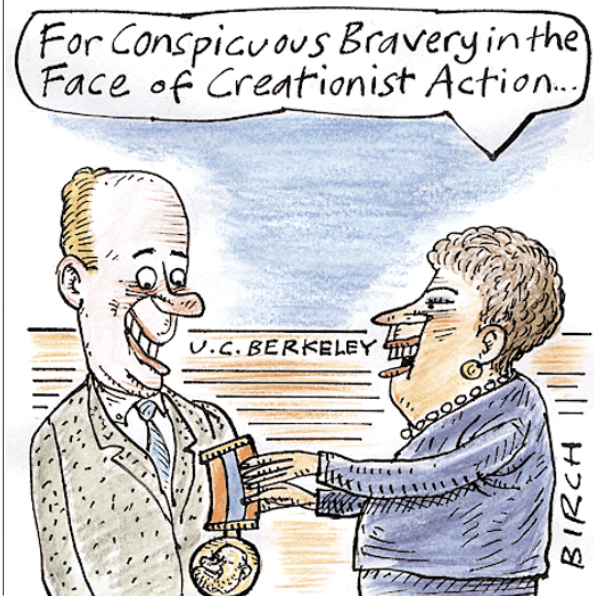

their members to become actively involved in teaching evolution.

Berkeley officials hope to receive $\$ 500,000$ from the US National Science Foundation to set up a website showing ways to teach evolution. The three-year project will also study its own effectiveness.

"We want to create one-stop shopping for evolution teaching for instructors, from kindergarten through the university level," said Judy Scotchmoor, coordinator of the evolution programme at Berkeley's Museum of Paleontology.

At the annual meeting of the SICB, whose 2,100 members are specialists in developmental biology, a discussion was held on how to ensure the widespread teaching of evolution.

Kevin Padian, a palaeontologist at Berkeley, told the meeting it was important that the chairs of university departments recognized the importance of allowing faculty to assist in grassroots efforts to further evolution teaching.

Professors should receive academic credit for engaging in the battle, said Padian, adding that "it is just as important as putting a paper in Nature, Science or the American Zoologist".

Ronald Edwards, an evolutionary biologist at DePaul University in Chicago, suggested that professors should not be confrontational or arrogant with students who have been taught creationism in their churches or homes.

"College students are willing to take on new ideas, but they won't if there is a hint of antagonism," said Edwards, who spoke of his experiences at Valdosta State University in Georgia, where many students believe in creationism.

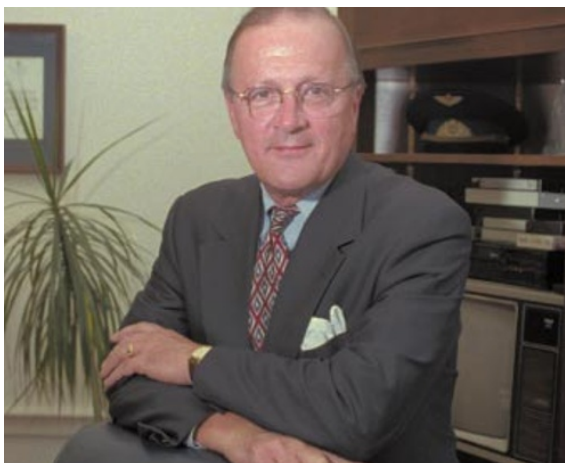

Man in the middle: Boehlert has used his moderation to build influence on Capitol Hill.

US research that is not medical or military, including the space agency NASA and civilian research at the Department of Energy as well as the NSF and NIST. As the only committee in either house of Congress devoted to science, it has traditionally served as an important forum for scientific issues.

But under its past two chairs, Robert Walker (Republican, Pennsylvania) and James Sensenbrenner (Republican, Wiscon$\sin$ ), science lobbyists have seen the committee as partisan and insufficiently committed to the cause of the research agencies under its jurisdiction.

Sensenbrenner alienated the scientific community by failing to back a bill that would have authorized the doubling of research spending, and by pursuing what many saw as a political vendetta against the Advanced Neutron Spallation Source project at the Oak Ridge National Laboratory in Tennessee.

Boehlert's arrival is likely to result in a resumption of the wide-ranging discussion of science that the committee conducted under its most recent Democratic chairman, the late and much-lamented George Brown. "We are going to move in the direction of committee staff having solid scientific backgrounds," says Boehlert.

As for fears that his moderate reputation will weaken the committee - Boehlert is the only one of 13 Republican House committee chairs named last week who is not seen as a conservative - he views it as a strength.

"I don't sense any isolation," he says. "I'm where the overwhelming majority of the American people are - in the middle ground."

Boehlert also hopes that his friendship with Senator John McCain (Republican, Arizona), which dates from their arrival in the House together in 1982, will help the Science Committee to get Senate attention for its legislative ideas. McCain is chair of the Senate's Commerce, Science and Transportation Committee. 